\title{
Promoting Home Prepared Soy-dishes for Fighting Protein-Energy Malnutrition: Evidence from Demonstration Training
}

\author{
Umer Asrat \\ Food Science and Nutrition Research Directorate, Pawe Agricultural Research Center \\ Ethiopian Institute of Agricultural Research, P.O. Box: 25, Ethiopia
}

\begin{abstract}
Malnutrition is a persistent problem in developing countries, and protein-energy malnutrition is the worst form of malnutrition associated with lack of energy and proteins. Malnutrition at the early stages of life can lower child resistance to infections, increase child morbidity and mortality, and decrease mental and cognitive achievement. Worldwide the most important step in the treatment of protein energy malnutrition is to correct nutritional imbalances. Increasing the amount of protein in cereal staple foods is the ideal solutions to problem related to malnutrition. Several studies reported that, increased protein content in soybean fortified cereals and tubers, which makes significant contribution towards the alleviation of protein-energy malnutrition. Soybean can be utilized mainly as fermented (e.g., sauce, miso, natto) and non-fermented (e.g., oil, milk, tofu, flour) foods. Therefore, this paper aimed to revise the contribution of home-prepared soy-dishes to combat protein-energy malnutrition.
\end{abstract}

Keywords: Malnutrition; protein-energy malnutrition; soybean; soy-dishes

DOI: $10.7176 / \mathrm{FSQM} / 105-03$

Publication date: February $28^{\text {th }} 2021$

\section{Introduction}

Malnutrition is globally the most important risk factor for illnesses and death, affecting especially hundreds of millions of pregnant women and young children (Ezzati et al., 2002). It is a persistent problem in developing countries, especially in rural areas where poor people depend on staple foods and have limited access to a diverse diet. There are several forms of malnutrition and these include two broad categories namely undernutrition and over nutrition. Undernutrition during the first two years of life can lead to stunting (low height for age) and wasting (low weight for height), and consequently to reduced mental and physical capacity later in life (WHO, 2009). It also leads to a higher susceptibility to infections and an increase in mortality due to common infections (USAID, 2016). Malnutrition can also be categorized as being either acute or chronic. Malnutrition is considered acute if it lasts for three months or less before resolving, and malnutrition is considered chronic if it persists for more than three months (Mehta et al., 2013).

Protein-energy malnutrition (PEM) is considered as the worst form of malnutrition associated with lack of energy and proteins (UNICEF, 2013). It is an imbalance between the supply of energy and protein, and the body's demand for them to ensure optimal growth and function. Globally, PEM continues to be a major health burden in developing countries and the most important risk factor for illnesses and death. It is currently the most widespread and serious health problem of children in the world being moderate or severe forms (USAID, 2002). Protein-energy malnutrition is also classified into kwashiorkor, marasmus, and marasmic-kwashiorkor. Kwashiorkor is a form of malnutrition caused by inadequate protein intake, while marasmus is caused by a lack of energy and protein within the diet (Thompson et al., 2008; Manary et al., 2009). Protein-energy malnutrition may be present at any time during the life cycle. Infants and children from developing countries and elderly people from all around the world are the two main groups suffering from protein-energy malnutrition (Lesourd and Mazari, 1997). In developing countries, protein-energy malnutrition problem is ascribed to the inappropriate complementary feeding practices, low nutritional quality of traditional complementary foods and high cost of quality protein-based complementary foods (Eka et al., 2010).

Malnutrition can be sustainably addressed through a cheap strategy of promoting consumption of nutritious foods or strategically blending locally available foods to produce nutrient-dense products (Akande et al., 2017). Several legumes have been studied and proposed as protein alternatives for human consumption, particularly in developing countries (Kutos et al., 2002). It has been documented that compositing legume proteins with those from cereal and root crops has a complementation effect producing complete and well-balanced amino acid profiles that meet human physiological requirements (Michaelsen et al., 2009). Soybean (Glycine max) among legumes is recognized for its high nutritional value as it contains about $40 \%$ protein, $20 \%$ oil, $23 \%$ carbohydrate and $4 \%$ minerals (Shiriki et al., 2015). The high nutritional value and low cost of soybean and soy-products make them a suitable solution for malnutrition problems for poor people living on grain centered diets (Serrazanetti et al., 2013). Thus, this review paper was aimed to revisit the benefits of soy-dishes in reducing 
protein-energy malnutrition and to indicate the existing opportunities for household consumption of soybean and soy-products.

\section{Prevalence of Malnutrition in Ethiopia}

Malnutrition occurs due to an imbalance in the body, whereby the nutrients required by the body and the amount used by the body do not balance (WHO, 2009). The most important documented forms of malnutrition in Ethiopia are protein-energy malnutrition (PEM) and micronutrient deficiencies (vitamin A, iodine and zinc). In Ethiopia, $40.40 \%$ of children were reported to be stunted (chronically malnourished) and country ranked $117^{\text {th }}$ of data available in 132 countries about children's stunting prevalence. About $8.70 \%$ of children under-five age are wasted (acute malnutrition) and country ranked $98^{\text {th }}$ position of 130 countries in wasting prevalence (Global Nutrition Report, 2016).

Rural areas are more likely to have a higher percentage of stunted children (46\%) in comparison to urban environments (36\%) in Ethiopia. Amhara has the highest percentage of stunted children at $52 \%$ followed by Tigray (51\%), Afar (50\%), and Benishangul-gumuz (49\%) (USAID, 2016). About 25\% of children under the age of five are underweight (EDHS, 2014), and 53\% of child mortality (under-five years of age) in Ethiopia is attributed to malnutrition. Factors such as improper feeding practices, limited micronutrient dietary selections, and a lack of introducing complementary nutritional foods at appropriate times are the leading causes of malnutrition in Ethiopia (USAID, 2016). Commercially formulated complementary foods are often of high cost thus inaccessible to low-income households. Moreover, animal sources of proteins, which are used to complement the cereal based diets are expensive and out of reach for low-income families (Obatolu et al., 2007).

\section{Soybean and Soy-products: Alternative Protein Sources}

Soybean products have emerged as one of the most economical and nutritious foods that can combat diseases ascribed to malnutrition and undernutrition in developing countries (Kumar et al., 2003). A wide variety of soyfoods (non-fermented and fermented) are available throughout the world today. Some are produced by modern processing methods in large-scale plants, and others are still in more traditional ways owing their history to oriental processing methods (Raghuvanshi and Bisht, 2010). Unfermented soybean products include soy-sprouts, immature green soybeans, roasted soybeans, soy-flour, soymilk, tofu, and okara while fermented soybean products include miso, tempeh, and soy sauce (Abiose et al., 2015). Soybean contains important macronutrients. Around $40 \%$ of the bean is relatively high biological value protein containing all essential amino acids. About the $20 \%$ of the bean is composed of lipids (15\% saturated fat, $61 \%$ polyunsaturated fat and $24 \%$ monounsaturated fat) (Cederroth and Nef, 2009).

Table 1. Amino acid compositions of soybean

\begin{tabular}{lccc}
\hline Amino acid & \multicolumn{3}{c}{$\mathrm{mg} / \mathrm{g}$ protein (dry matter basis) } \\
\cline { 2 - 4 } & (Fukushima, 1991) & (Friedman, 1996) & (USDA, 2003) \\
\hline Histidine & 27.0 & 25.4 & 27.51 \\
Isoleucine & 48.0 & 47.1 & 49.42 \\
Leucine & 78.0 & 85.1 & 82.97 \\
Lysine & 61.0 & 63.4 & 67.85 \\
Methionine + cysteine & 65.0 & 68.1 & - \\
Phenylalanine + tyrosine & 90.0 & 96.6 & 91.80 \\
Tryptophan & 13.0 & 11.4 & 14.82 \\
Threonine & 35.0 & 38.4 & 44.28 \\
Valine & 48.0 & 49.1 & 50.88 \\
\hline
\end{tabular}

Source: Fukushima, 1991; Friedman, 1996; USDA, 2003

Soy protein quality is equivalent to that of livestock proteins (meat and milks) in terms of protein digestibility corrected amino acids score (PDCAAS), and is superior to other plant proteins (Giri and Mangaraj, 2012). Soy protein is also effective in lowering total cholesterol as well as low-density lipoprotein (LDL) cholesterol (Anderson et al., 1995). The consumption of soybean products containing soy protein has risen in recent years (Giri and Mangaraj, 2012). Soybean proteins are used in human foods in a variety of forms, including infant formulas, flours, protein isolates and concentrates, and texturizing fibers (Singh et al., 2000). The high nutritional value and low cost of soybean products make them a suitable solution for malnutrition problems for poor people living on grain centered diets (FDA, 2004). Evidence also suggests that soy-based complementary foods have played a reputable role in reducing protein energy malnutrition among African children (Muhimbula et al., 2011; Onoja et al., 2014). Soybean flour and soybean protein has been used as composite flour in the production of bread (Olaoye et al., 2006), missi roti/chapatti (Kadam et al., 2012) and biscuit (Oluwamukomi et al., 2011). Mosha et al. (2010) reported that, soybean composite crackers have also been developed as energy dense healthy snack for school-children. 


\section{Demonstration and Popularization of Soybean-dishes}

Because of its high protein content and low price, soybean and its products are considered as an aid in solving world food problems. For thousands of years, soybean has been a staple of the Asian diet, but over recent decades, consumption is quickly growing worldwide (Lokuruka, 2010). In Ethiopia, soybean is adapted to diverse ecological niches and provided wider yield range. Currently, the production is steadily growing to meet the ever-increasing food and market demands of this crop in the country. Soybean could be an alternative protein source to the rural families and can be utilized at home in various forms (Ambitsi and Oucho, 2007). Different soybean-based products; soymilk, soy-cheese, wot (stews), kitta (unleavened bread), dabbo (traditional bread), dabo-kolo, injera (fermented flat bread), fried okara and other products have been prepared and demonstrated successfully in Metekel Zone and Jawi Districts.

Table 2. Different types of soybean-based dishes prepared at home level

\begin{tabular}{|c|c|c|}
\hline No. & $\begin{array}{l}\text { Soybean-based } \\
\text { dishes }\end{array}$ & Preparation methods \\
\hline 1 & Soymilk & $\begin{array}{l}\text { Cleaned seeds will be blanched for } 10 \text { mins and soaked in water (soybean: water } \\
\text { ratio } 1: 3, \mathrm{w} / \mathrm{v} \text { ) overnight at room temperature. Hydrated beans will be drained, } \\
\text { rinsed and de-hulled manually, then wet-milled with the hot water (soybean: water } \\
\text { ratio } 1: 8, \mathrm{w} / \mathrm{v} \text { ). The slurry will be cooked for } 15 \text { mins and filtered using cheese } \\
\text { cloth and boiled for another } 10 \text { minutes and cooled. Then, ready for consumptions } \\
\text { with sugar, salt and spices (rue, cinnamon and clove) }\end{array}$ \\
\hline 2 & Soy-cheese & $\begin{array}{l}\text { First soymilk will be prepared according to the above procedure, and then the } \\
\text { temperature will be waited till lowered to } 75^{\circ} \mathrm{C} \text {. Then, about } 100 \mathrm{ml} \text { of filtered } \\
\text { lemon juice will be added for about } 1000 \mathrm{ml} \text { of soymilk as a coagulant. Once } \\
\text { stirred the mixture will be kept until coagulated. Then, the mixtures will be poured } \\
\text { over muslin cloth and the liquid will be pressed out. }\end{array}$ \\
\hline 3 & $\begin{array}{l}\text { Soy-teff blended } \\
\text { injera }\end{array}$ & $\begin{array}{l}\text { First soybean and teff mixed flours will be prepared in } 20: 80 \text { ratio (soybean: teff). } \\
\text { About } 300 \mathrm{~g} \text { soy-teff mixed flour }(240 \mathrm{~g} \text { teff }+60 \mathrm{~g} \text { soy) will be taken, and mixed } \\
\text { with } 40 \mathrm{~g} \text { irsho and } 1000 \mathrm{ml} \text { water. Then, allowed to ferment for } 50 \text { hrs. After } \\
\text { primary fermentation, about } 300 \mathrm{ml} \text { hot water (absit) will be added and mixed. } \\
\text { Then, allowed to cool for about } 30 \mathrm{mins} \text { and } 180 \mathrm{ml} \text { water will be added, and } \\
\text { waited for secondary fermentation. Then, it will be baked following traditional } \\
\text { injera baking procedure. }\end{array}$ \\
\hline 4 & $\begin{array}{l}\text { Soy-wheat blended } \\
\text { bread (dafo-dabo) }\end{array}$ & $\begin{array}{l}\text { By taking soybean and teff mixed flour in prepared } 25: 75 \text { ratio (soy: wheat), } \\
\text { traditional bread can be prepared following the traditional dafo-dabo making } \\
\text { procedure. }\end{array}$ \\
\hline 5 & $\begin{array}{l}\text { Cookies, dabo- } \\
\text { kollo, kitta and } \\
\text { chechebsa }\end{array}$ & $\begin{array}{l}\text { Soy-wheat blended cookies, dabo-kollo, kita and chechebsa also can be prepared } \\
\text { by mixing soybean and wheat flour in } 1: 3 \text { ratio }(50 \mathrm{~g} \text { soy }+150 \mathrm{~g} \text { wheat flour) in } \\
\text { home level following traditional procedure. }\end{array}$ \\
\hline 6 & $\begin{array}{l}\text { Soy-finger millet } \\
\text { blended porridge }\end{array}$ & $\begin{array}{l}\text { About } 40 \mathrm{~g} \text { soy-flour and } 160 \mathrm{~g} \text { finger millet flour }(20: 80) \text { will be mixed and cooked } \\
\text { in } 500 \mathrm{ml} \text { hot water following traditional procedure and possible to consume with } \\
\text { butter/oil and pepper. }\end{array}$ \\
\hline 7 & Okara & $\begin{array}{l}\text { Okara is the insoluble fibrous material from filtered soymilk. It can be fried and } \\
\text { consumed using oil with carrot, kale, onion and other spices. }\end{array}$ \\
\hline
\end{tabular}

Practical training on how to prepared common and traditional food products by blending soybean with other cereal grains was given for selected participants from jawi, pawe, mandura, dangur, and dibate woredas. On the training session 36-female farmers, 4-male farmers and 4-AHEW (Agricultural and Health Extension Workers) from jawi woreda, 27-female farmers and 26-AHEW from pawe woreda, 44-female farmers and 4-AHEW from mandura and dangur woredas, and 27-female farmers and 3-agricultural extension experts from dibate woreda were participated. 


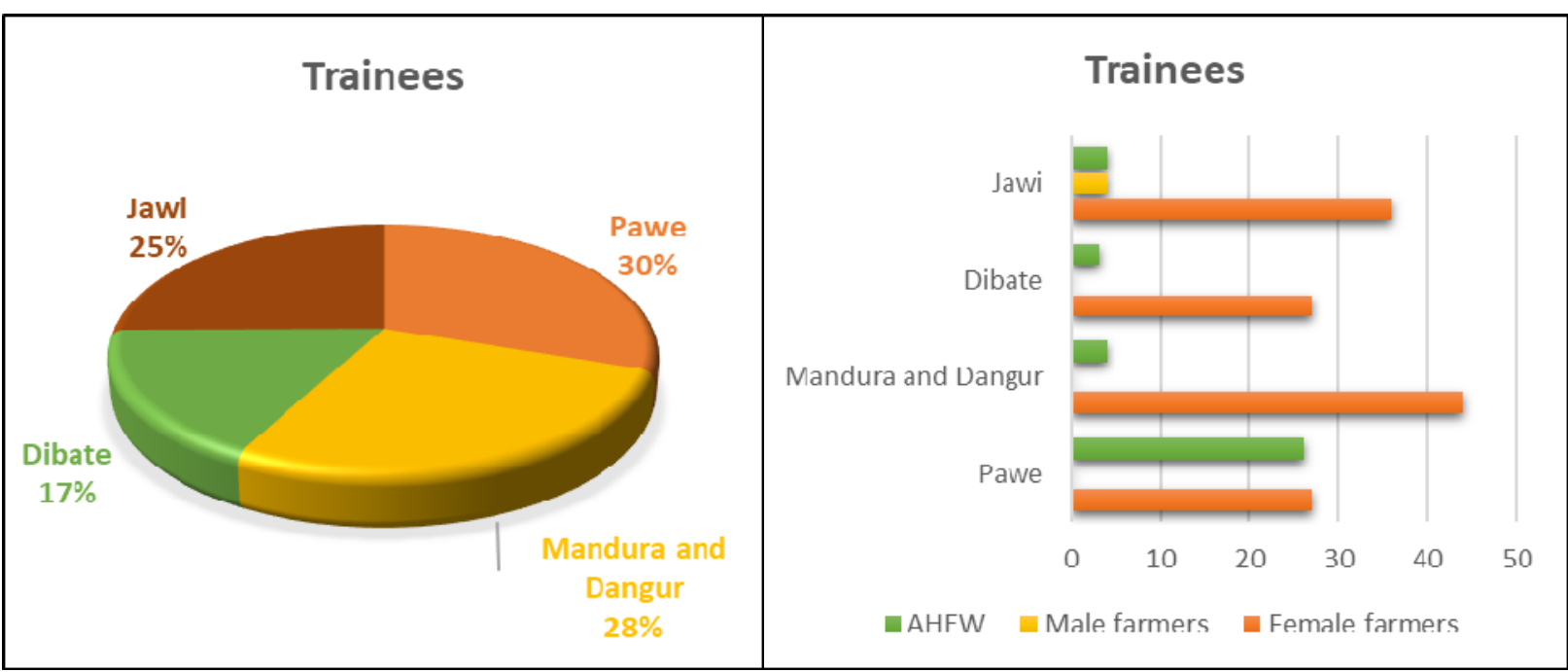

Figure 1. Participants on soy-dishes training

\section{Conclusions}

Protein deficiency and malnutrition is a well-documented cause of ill health and death in developing countries. The causes are numerous and multifaceted but the immediate determinants are poor diet and disease. Food-based strategies favoring local multi-nutrient food materials have been reported to be the best suitable and sustainable approach for combating protein malnutrition. Thus, soybean is easily available, cheap, and a rich source of protein for poor farmers, who have less access to animal source protein due to their low purchasing capacity. In extension program, different soybean-based food products were prepared and demonstrated, and farmers (male and female), agricultural and health extension workers were also trained how to prepare soy-dishes at home level. Promising result was observed, and further promotion of soy-dishes for household consumption is importation to tackle malnutrition related problems.

\section{References}

Abiose, S. H., Ikujenlola, A. V., \& Abioderin, F. I. (2015). Nutritional quality assessment of complementary foods produced from fermented and malted quality protein maize fortified with soybean flour. Polish Journal of Food and Nutrition Science, 65(1): 49-56.

Akande, O. A., Nakimbugwe, D., \& Mukisa, I. M. (2017). Optimization of extrusion conditions for the production of instant grain amaranth-based porridge flour. Food Sci. Nutr., 5: 1205-1214.

Ambitsi, N. E. O. \& P. Oucho. (2007). Assessment of adoption of soybean processing and utilization technologies in Navakholo and Mumias Divisions of western Kenya. Kenya Agricultural Research Institute, 1434-1438.

Anderson, J. W., B. M. Johnstone, \& M. L. Cook-Newell. (1995). Meta-analysis of the effects of soy protein intake on serum lipids. N. Engl. J. Med., 333:276.

Cederroth, C. R. \& Nef, S. (2009). Soy, phytoestrogens and metabolism: A review. Molecular and cellular endocrinology special issue: endocrine disruptors from the environment in the aetiology of obesity and diabetes, 304(1-2): 30-42.

EDHS. (2014). Ethiopia Mini Demographic and Health Survey. Central Statistical Agency, Addis Ababa, Ethiopia.

Eka, B. E., Abbey, B. W., \& Akaninwor, J. O. (2010). Nutritional evaluation of some traditional weaning foods from Akwa Ibom State, Nigeria. Nigerian Journal of Biochemistry and Molecular Biology, 25: 65-72.

Ezzati, M., Lopez, A. D., Rodgers, A., Vander, H. S., \& Murray, C. J. (2002). Selected major risk factors and global and regional burden of disease. Lancet, 360: 1347-1360.

FDA. (2004). Soy protein and the reduce risk of certain cancers. Health Claim Petition, 1-97.

Friedman, M. (1996). Nutritional value of proteins from different food sources. A review. Journal of Agricultural and Food Chemistry, 44: 6-29

Fukushima, D. (1991). Recent progress of soybean protein foods: chemistry, technology and nutrition. Food Reviews International, 7: 323-352.

Giri, S. K. \& Mangaraj, S. (2012). Processing influences on composition and quality attributes of soymilk and its powder - a review. Food Eng. Rev., 4(3): 149-164.

Global Nutrition Report. (2016). Global nutrition report from promise to impact: Ending malnutrition by 2030. Washington, DC: International Food Policy Research Institute. 
Kadam, M. L., Salve, R. V., Mehrajfatema, Z. M., \& More, S. G. (2012). Development and evaluation of composite flour for Missi roti/chapatti. Food Processing and Technology, 3: 134.

Kumar, V., Rani, A., Tindwani, C., \& Jain, M. (2003). Lipoxygenase isozymes and trypsin inhibitor activities in soybean as influenced by growing location. Food Chemistry, 83: 79-83.

Kutos, T., Golob, T., Kac, M., \& Plestenjak, A. (2002). Dietary fiber of dry processed beans. Food Chemistry, 80: 231-235.

Lesourd B. M., \& Mazari L. (1997). Immune responses during recovery from protein-energy malnutrition. Clinical Nutrition, 16: 37-46.

Lokuruka, M. (2010). Soya nutritional properties. African Journal of Food Agriculture Nutrition and Development, 10(4): 20-29.

Manary, J. M., Heikens, G. T., \& Golden, M. (2009). Kwashiokor: More Hypothesis Testing is needed to understand the Aetiology of Oedema. Malawi Med. J., 21(3): 106-107.

Mehta, N. M., Corkins, M. R., \& Lyman, B. (2013). Defining pediatric malnutrition: a paradigm shifts toward etiology-related definitions. J. of Parenter. Enteral Nutr., 37(4): 460-481.

Michaelsen, K. F., Floppe, C., Root, N., Kaestel, P., Stougard, M., Laurtzen, L., Molgard, C., Girma, T., \& Friis, H. (2009). Choice of food ingredient for moderately malnourished children 6 month to 5 years of age. Journal of Food and Nutrition, 30: 1-62.

Mosha, T. C. E., Laswai, H. S., \& Tetens, I. (2000). Nutritional composition and micronutrient status of homemade and commercial weaning foods consumed in Tanzania. Plant Foods for Human Nutrition, 55: 186-203.

Muhimbula, H. S., Issa-zacharia, A., \& Kinabo, J. (2011). Formulation and sensory evaluation of complementary foods from local, cheap and readily available cereals and legumes in Iringa, Tanzania. African Journal of Food Science, 5(1): 26-31.

Obatolu, V. A., Augustine, O., \& Iken, J. E. (2007). Improvement of homemade maize tortilla with soybean. International Journal of Food Science and Technology, 42: 420-426.

Olaoye, O. A., Onilude, A. A., \& Idowu, O. A. (2006). Quality characteristics of bread produced from composite flours of wheat, plantain and soybeans. African Journal of Biotechnology, 5: 1102-1106.

Oluwamukomi, M. O., Oluwana, I. B., \& Akinbowale, O. F. (2011). Physicochemical and sensory properties of wheat-cassava composite biscuit enriched with soy flour. African Journal of Food Science, 5(2): 50-56.

Onoja, Akubor, Gernar, \& Chinmma. (2014). Evaluation of complementary food formulated from local staples and fortified with calcium, iron and zinc. Journal of Nutrition and Food Sciences, 4(6). doi.org/10.4172/2155-9600.1000326

Raghuvanshi, R. S., \& Bisht, K. (2010). Uses of soybean: products and preparation. pp.404-426. In: G. Singh (ed.), The Soybean: Botany, Production and Uses. CAB International, Wallingford, Oxfordshire OX10 8DE, UK.

Serrazanetti, D. I., Ndagijimana, M., Miserocchi, C., Perillo, L., \& Guerzoni, M. E. (2013). Fermented tofu: Enhancement of keeping quality and sensorial properties. Food Control, 34(2): 336-346.

Shiriki, D., Igyor, M., A. \& Gernah, D. I. (2015). Nutritional evaluation of complementary food formulations from maize, soybean and peanut fortified with moringa oleifera leaf powder. Food and Nutrition Sciences, 6: 494-500.

Singh, R., Singh, G., \& Chauhan, G. (2000). Nutritional evaluation of soy fortified biscuits. J. Food Sci. Technol., 37(2): 162-164.

Thompson, J. L., Manore, M. M. \& Vaughan, A. V. (2008). The Science of Nutrition. Pearson Education Publishing: San Francisco, CA. pp 220-259.

UNICEF. (2013). Improving child nutrition the achievable imperative for global progress, 3, United Nations Plaza, New York, USA. Available at: www.unicef.org/publications/index.html

USAID. (2002). Commodities reference guide- part I and module II: material of child health and nutrition. Available at: http://www.nutritionfacts.htm.

USAID. (2016). Ethiopia: Nutrition Profile. Available at: https://www.usaid.gov/what-we-do/globalhealth/nutrition/countries/ethiopia-nutrition-profile.

USDA. (2003). National nutrient database for standard reference. Legumes and legume products. Available at: http://www.ars.usda.gov/SP2UserFiles/Place/12354500/Data/SR24/reports/sr24fg16.pdf

WHO. 2009. Infant and young child feeding. Model Chapter for textbooks for medical students and allied health professionals. Geneva, Switzerland. 

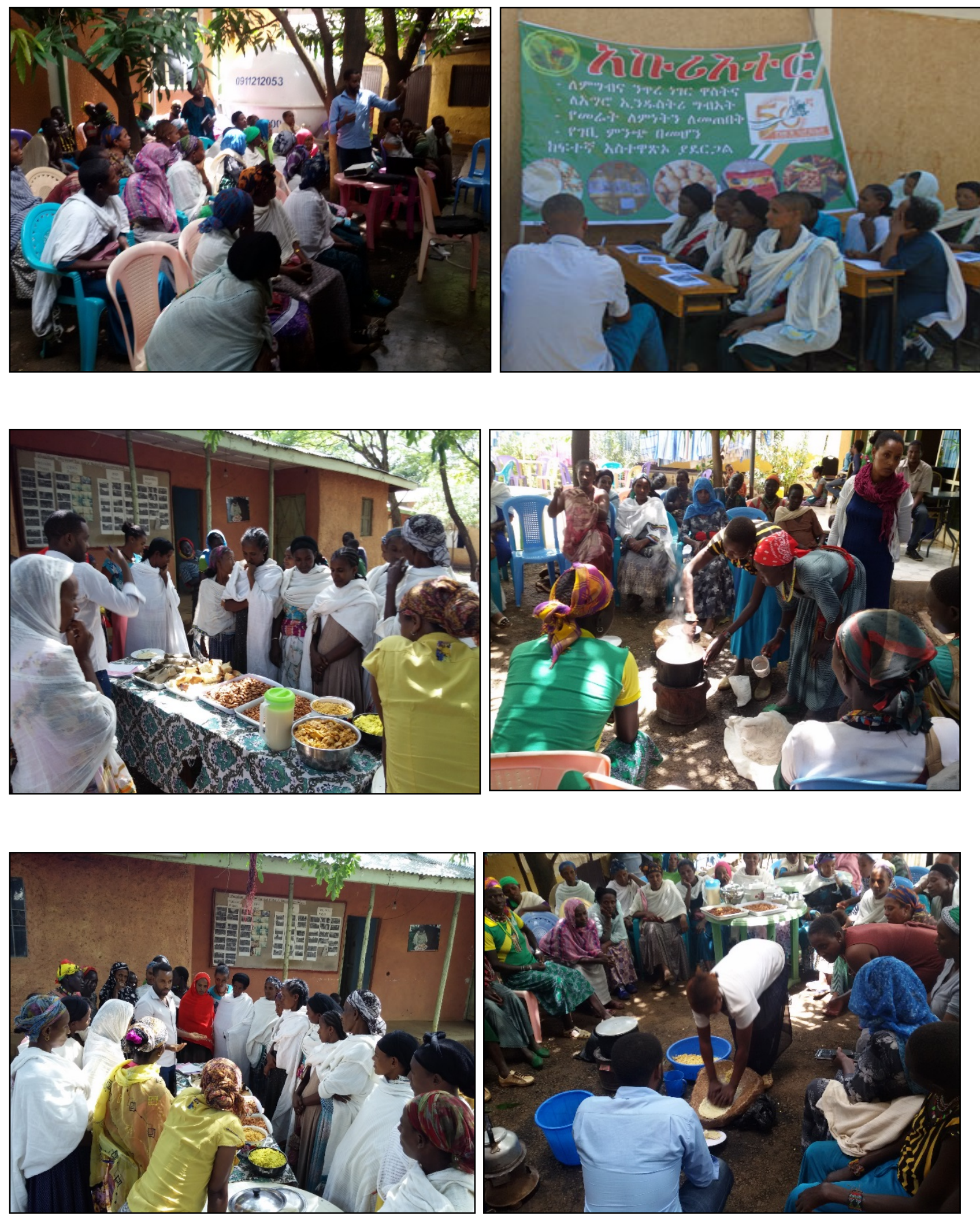

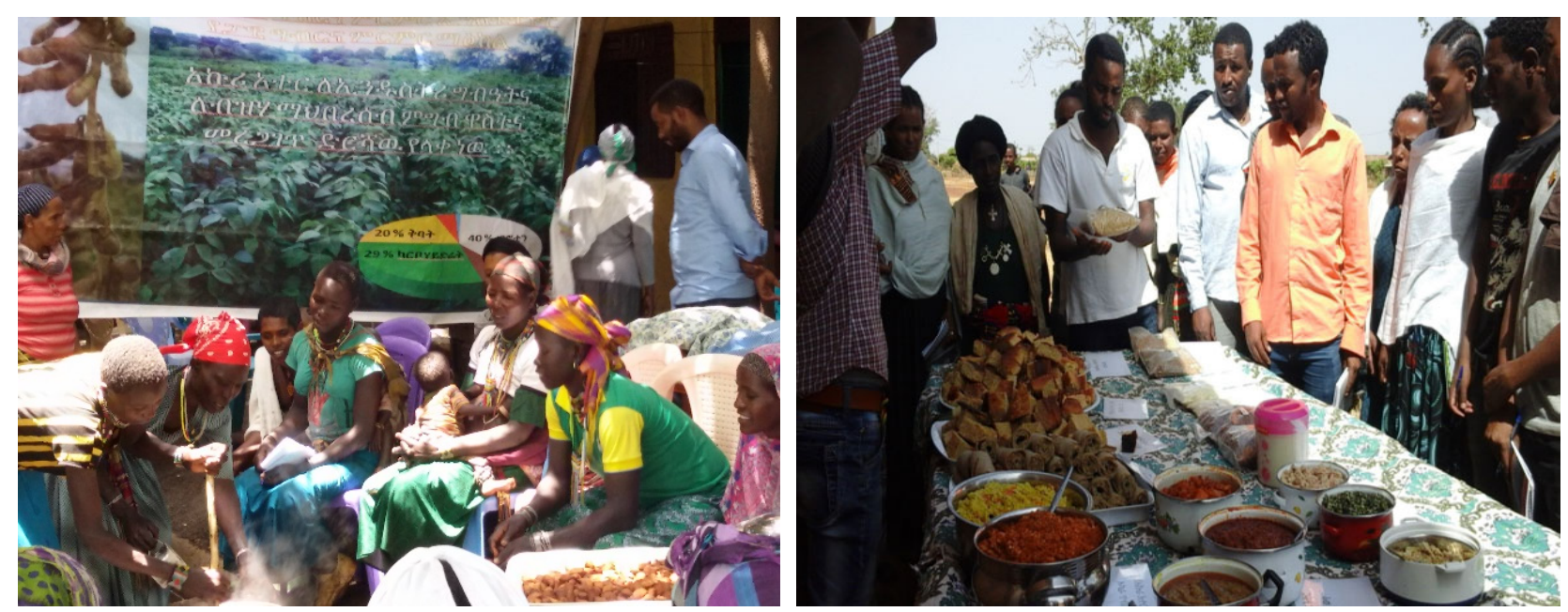

Figure 2. Practical training on how to prepared soy-based dishes at home level 